\title{
Yeast microbiota of raptors: a possible tool for environmental monitoring
}

Raimunda S. N. Brilhante, ${ }^{1 *}$

Débora S. C. M. Castelo Branco, ${ }^{1}$

Guilherme P. S. Duarte, ${ }^{2}$ Manoel A. N. Paiva, ${ }^{2}$

Carlos E. C. Teixeira, ${ }^{1}$ João P. O. Zeferino, ${ }^{2}$

André J. Monteiro, ${ }^{3}$ Rossana A. Cordeiro ${ }^{1}$

José J. C. Sidrim ${ }^{1}$ and Marcos F. G. Rocha ${ }^{1,2}$

${ }^{1}$ Postgraduate Program in Medical Microbiology, Specialized Medical Mycology Center, Federal

University of Ceará, Rua Coronel Nunes de Melo, $s / n$, Rodolfo Teófilo. CEP: 60430270, Fortaleza-CE, Brazil. ${ }^{2} S c h o o l$ of Veterinary Medicine, Postgraduate Program in Veterinary Science, State University of Ceará, Av. Paranjana, 1700. CEP: 60.740-903, Fortaleza-CE, Brazil.

${ }^{3}$ Department of Statistics and Applied Mathematics, Federal University of Ceará, Fortaleza-CE, Brazil.

\section{Summary}

Twenty-two raptors from a rehabilitation centre were evaluated for the presence of yeasts prior to returning them to the wild, and the recovered Candida isolates were tested for in vitro antifungal susceptibility and phospholipase production. Samples were collected from the crop/lower esophagus and cloaca. In vitro antifungal susceptibility and phospholipase production of 21 Candida strains were assessed through broth microdilution and growth on egg yolk agar respectively. Twenty-seven isolates, belonging to seven species, were recovered from 16 tested birds, with $C$. albicans and $C$. famata as the most prevalent species. Three out of 21 isolates (2 C. albicans and 1 c. tropicalis) were simultaneously resistant to fluconazole and itraconazole. As for phospholipase production, $8(8 / 21)$ isolates $(6 \mathrm{C}$. albicans, 1 C. famata and 1 C. parapsilosis) showed enzymatic activity. The most relevant finding in this study was the isolation of resistant Candida spp. from wild raptors that had never been submitted to antifungal therapy, which suggests exposure to environmental contaminants. Based on this, we propose the assessment of

Received 27 June, 2011; revised 10 November, 2011; accepted 27 November, 2011. *For correspondence. E-mail brilhante@ufc.br; Tel. (+55) 853366 8319; Fax (+55) 8532951736.

() 2012 Society for Applied Microbiology and Blackwell Publishing Ltd
Candida spp. from the gastrointestinal tract of raptors as a tool for environmental monitoring.

Introduction

Raptors belong to the avian orders Ciconiiformes and Strigiformes, which include eagles, hawks, owls and vultures (ITIS, 2011). They are commonly found in Brazilian wild animal rehabilitation centres, mainly, due to traumarelated health disorders and illegal trade (ICMBio, 2008).

According to Brazilian legislation, before releasing birds into their natural environments, they should be screened for some pathogens, including Candida spp. and Cryptococcus spp. Such procedures are routinely performed at the Triage Center for Wild Animals (CETAS) of the Brazilian Institute of Environment and Renewable Natural Resources (IBAMA), where injured or seized wild animals are kept until they are rehabilitated and fit to be released. In this study, 22 raptors from CETAS were evaluated for the presence of yeasts, prior to returning them to the wild, and the recovered Candida isolates were tested for in vitro antifungal susceptibility and phospholipase production.

\section{Results and discussion}

Twenty-two raptors, belonging to seven different species, were assessed: 8 roadside hawks (Rupornis magnirostris), 6 savanna hawks (Heterospizias meridionalis) 4 caracaras (Caracara plancus), 1 American black vulture (Coragyps atratus), 1 yellow-headed caracara (Milvago chimachima), 1 Harris's hawk (Parabuteo unicinctus) and 1 barn owl (Tyto alba). The specimens M. chimachima, $P$. unicinctus and T. alba had been captured for illegal trade and were seized by IBAMA and taken to the triage centre (CETAS), where they were kept for a long period of time. The other specimens were taken from the wild to CETAS for presenting trauma-related disorders, where they spent a short period of time because they were released as soon as they recovered. While in captivity, they were maintained in collective enclosures and their diet mainly consisted of beef supplemented with minerals and vitamins. This study was approved (protocol number 02/09) by the Animal Research Ethics Committee of the Federal University of Ceará. 
Table 1. Yeast isolated from the gastrointestinal tract of raptors and in vitro antifungal susceptibility and phospholipase production of the recovered Candida spp.

\begin{tabular}{|c|c|c|c|c|c|c|c|}
\hline \multirow[b]{2}{*}{ Bird species } & \multirow{2}{*}{$\begin{array}{l}\text { Positive } \\
\text { /tested } \\
\text { birds }\end{array}$} & \multirow[b]{2}{*}{ Collection site } & \multirow[b]{2}{*}{ Yeast species } & \multicolumn{3}{|c|}{ Minimum inhibitory concentration $\left(\mu \mathrm{g} \mathrm{ml}^{-1}\right)$} & \multirow{2}{*}{$\begin{array}{l}\text { Phospholipase } \\
\text { production }\end{array}$} \\
\hline & & & & Amphotericin B & Fluconazole & Itraconazole & \\
\hline \multirow[t]{4}{*}{ Caracara plancus } & \multirow[t]{4}{*}{$3 / 4$} & \multirow[t]{2}{*}{ Crop/lower esophagus } & T. asteroides $(1)^{\mathrm{a}}$ & - & - & - & - \\
\hline & & & R. mucilaginosa (1) & - & - & - & - \\
\hline & & \multirow[t]{2}{*}{ Cloaca } & C. albicans (1) & 0.5 & 4 & 0.5 & 0.36 \\
\hline & & & C. famata (1) & 0.25 & 1 & 0.03125 & 1 \\
\hline Coragyps. atratus & $1 / 1$ & Cloaca & C. albicans (1) & 0.125 & $>64^{b}$ & $>16^{\mathrm{b}}$ & 0.53 \\
\hline \multirow{5}{*}{$\begin{array}{l}\text { Heterospizias } \\
\quad \text { meridionalis }\end{array}$} & \multirow[t]{5}{*}{$3 / 6$} & \multirow[t]{4}{*}{ Crop/lower esophagus } & C. albicans (1) & 0.5 & 0.25 & 0.03125 & 1 \\
\hline & & & C. famata (1) & 0.25 & 1 & 0.0625 & 0.68 \\
\hline & & & C. parapsilosis (1) & 0.25 & 0.25 & 0.0625 & 0.97 \\
\hline & & & R. mucilaginosa (1) & - & - & - & - \\
\hline & & Cloaca & C. parapsilosis (1) & 0.125 & 4 & 0.03125 & 1 \\
\hline \multirow[t]{2}{*}{ Milvago chimachima } & \multirow[t]{2}{*}{$1 / 1$} & \multirow[t]{2}{*}{ Cloaca } & C. albicans (1) & 0.25 & 1 & 0.03125 & 0.42 \\
\hline & & & C. famata (1) & - & - & - & 1 \\
\hline Parabuteo unicinctus & $1 / 1$ & Crop/lower esophagus & C. famata (1) & 0.25 & 1 & 0.0625 & 1 \\
\hline \multirow[t]{8}{*}{ Rupornis magnirostris } & \multirow[t]{8}{*}{$6 / 8$} & \multirow[t]{4}{*}{ Crop/lower esophagus } & C. albicans (3) & $0.5-1$ & $0.5->64^{b}$ & $0.125->16^{b}$ & $0.47,0.55,1$ \\
\hline & & & C. famata (3) & $0.125-0.5$ & $0.5-16$ & $0.0625-0.125$ & 1 \\
\hline & & & C. tropicalis (2) & $0.03125-0.5$ & $1 \rightarrow 64^{b}$ & $0.125->16^{b}$ & 1 \\
\hline & & & R. mucilaginosa (1) & - & - & - & - \\
\hline & & \multirow[t]{4}{*}{ Cloaca } & C. albicans (1) & 0.5 & 0.5 & 0.03125 & 0.39 \\
\hline & & & C. catenulata (1) & - & - & - & 1 \\
\hline & & & C. parapsilosis (1) & 0.5 & 0.5 & 0.03125 & 1 \\
\hline & & & C. tropicalis(1) & 0.25 & 1 & 0.125 & 1 \\
\hline T. alba & $1 / 1$ & Cloaca & C. famata (1) & 1 & 8 & 0.03125 & 1 \\
\hline
\end{tabular}

a. Number of recovered isolates.

b. Resistant isolates.

Prior to specimen collection, the birds were clinically evaluated (Brilhante et al., 2010). Only healthy birds were tested. Samples were collected from the crop/lower esophagus and cloaca and processed on birdseed (Guizotia abyssinica) agar supplemented with chloramphenicol $\left(0.5 \mathrm{~g} \mathrm{l}^{-1}\right)$ and biphenyl $(0.1 \%)$, at the Specialized Medical Mycology Center of Federal University of Ceará, Brazil, as previously described (Brilhante et al., 2010). Recovered colonies were identified through micromorphological and biochemical parameters. VITEK $2^{\circledR}$ (bioMérieux, USA) was used to confirm dubious identification (Brilhante et al., 2010).

Sixteen out of the 22 evaluated birds (72.73\%; 6/8 R. magnirostris, 3/6 H. meridionalis, 3/4 C. plancus, $1 / 1$ C. atratus, 1/1 M. chimachima, 1/1 P. unicinctus and 1/1 T. alba) were positive for the presence of yeasts (Table 1). Yeasts were recovered from crop/lower esophagus, cloaca or both anatomical sites of eight (50\%), five $(31.25 \%)$ and three $(18.75 \%)$ birds respectively.

A total of 27 isolates were obtained, with $C$. albicans $(n=8)$ and $C$. famata $(n=8)$ as the most prevalent ones, followed by $C$. parapsilosis $(n=3), C$. tropicalis $(n=3)$, Rhodotorula mucilaginosa $(n=3), C$. catenulata $(n=1)$ and Trichosporon asteroides $(n=1)$ (Table 1$)$. Four individuals simultaneously presented two yeast species in the crop, which were $C$. parapsilosis and $R$. mucilaginosa from one $H$. meridionalis and $C$. albicans and $C$. famata; C. albicans and C. tropicalis or $C$. famata and $R$ mucilagi- nosa from three $R$. magnirostris. In addition, two yeast species ( $C$. albicans and $C$. famata) were simultaneously isolated from the cloaca of two birds ( 1 C. plancus and 1 $M$. chimachima) and only one bird ( $R$. magnirostris) presented two yeast species in both anatomical sites (C. famata and C. tropicalis in the crop; C. catenulata and C. tropicalis in the cloaca). This last animal was the only one from which one species (C. tropicalis) was recovered from both evaluated sites.

Even though it is reported that the composition of the gastrointestinal yeast microbiota varies according to species-specific aspects, such as diet (Cafarchia et al., 2006a), in reality, it does not seem to vary greatly, considering that the yeast species recovered in this study were similar among the evaluated bird species and to other reports concerning other avian groups, such as psittacines (Vieira and Acqua-Coutinho, 2009; Brilhante et al., 2010) and ostriches (Melville et al., 2004). Unlike what was expected, based on previous reports (Cafarchia et al., 2006b), Cryptococcus spp. isolates were not recovered.

Twenty-one Candida isolates were submitted to antifungal susceptibility test: 8 C. albicans (4 from the crop/lower esophagus and 4 from the cloaca); 7 C. famata (5 from the crop/lower esophagus and 2 from the cloaca); 3 C. parapsilosis (1 from the crop/lower esophagus and 2 from the cloaca) and 3 C. tropicalis (2 from the crop/lower esophagus and 1 from the cloaca). 
The antifungal MICs for these microorganisms were determined through broth microdilution method, as recommended by the Clinical and Laboratory Standards Institute, document M27-A3. The microdilution plates were read after 24 and $48 \mathrm{~h}$ of incubation at $35^{\circ} \mathrm{C}$, but the MIC values considered were those obtained after $48 \mathrm{~h}$ of growth. MICs for fluconazole (Pfizer, Brazil) and itraconazole (Janssen Pharmaceutica, Belgium) were defined as the lowest drug concentration capable of inhibiting $50 \%$ of growth when compared with the growth control well, and for amphotericin B (Sigma Chemical Corporation, USA), it was defined as the lowest concentration at which no growth was observed. MICs of $>1, \geq 1$ and $\geq 64 \mu \mathrm{g} \mathrm{ml}^{-1}$ indicated resistance to amphotericin $\mathrm{B}$, itraconazole and fluconazole respectively (CLSI, 2008; Sidrim et al., 2010; Brilhante et al., 2011). However, for C. albicans, C. parapsilosis and $C$. tropicalis the considered breakpoint for fluconazole was $\geq 8 \mu \mathrm{g} \mathrm{ml}^{-1}$ (Pfaller et al., 2010). All strains were tested in duplicate and the assay was repeated, when resistance was detected, in order to confirm the results.

All Candida isolates were screened for phospholipase production, on egg yolk agar, as previously described (Price et al., 1982). Phospholipase activity (Pz) was determined by calculating the ratio between the diameter of the fungal colony and the total diameter, including the colony and the precipitation zone. $\mathrm{Pz}=1$ indicated negativity for phospholipase production; $\mathrm{Pz}<1$ indicated positivity for phospholipase activity and $\mathrm{Pz}<0.64$ indicated strong enzymatic activity (Price et al., 1982; Sidrim et al., 2010; Brilhante et al., 2011).

MICs for amphotericin $B$ ranged from 0.031 to $1 \mu \mathrm{g} \mathrm{ml}^{-1}$ $\left(\mathrm{MIC50}=0.25 \mu \mathrm{g} \mathrm{ml}^{-1}\right.$; MIC90 $\left.=1 \mu \mathrm{g} \mathrm{ml}^{-1}\right)$. For fluconazole and itraconazole, MICs varied from 0.125 to $>64 \mu \mathrm{g} \mathrm{ml}^{-1} \quad\left(\mathrm{MIC50}=1 \mu \mathrm{g} \mathrm{ml}^{-1} ; \quad\right.$ MIC90 $\left.\geq 64 \mu \mathrm{g} \mathrm{ml}^{-1}\right)$ and from 0.031 to $>16 \mu \mathrm{g} \mathrm{ml}^{-1}$ (MIC50 $=0.0625 \mu \mathrm{g} \mathrm{ml}^{-1}$; MIC90 $\geq 16 \mu \mathrm{g} \mathrm{ml}^{-1}$ ) respectively (Table 1$)$. Three isolates (3/21) (two $C$. albicans and one $C$. tropicalis) exhibited in vitro antifungal resistance and were resistant to both azole derivatives.

Parallely, these resistant strains were tested against promethazine, which is an inhibitor of efflux pumps (Kolaczkowski et al., 2003), and an MIC of $98 \mu \mathrm{g} \mathrm{ml}^{-1}$ was obtained for all tested isolates. After MIC determination, each isolate was tested against fluconazole and itraconazole combined with promethazine at $20 \mu \mathrm{g} \mathrm{ml}^{-1}$. MICs for fluconazole dropped from $>64$ to $2 \mu \mathrm{g} \mathrm{ml}^{-1}$ for both $C$. albicans strains and from $>64$ to $16 \mu \mathrm{g} \mathrm{ml}^{-1}$ for the $C$. tropicalis isolate. As for itraconazole, MICs declined from $>16$ to $0.0625 \mu \mathrm{g} \mathrm{ml}^{-1}$ for all three strains. These data suggest that the antifungal resistance observed for these Candida isolates was possibly associated with the overexpression of efflux pumps, since pump inhibition resulted in the decrease of azole MICs.
As for phospholipase production, out of the 23 tested Candida isolates, eight produced phospholipase (6 C. albicans, $1 \mathrm{C}$. famata and $1 \mathrm{C}$. parapsilosis). Although the sampled raptors were apparently healthy, all six positive C. albicans isolates presented strong enzymatic activity, with $\mathrm{PZ}$ values ranging from 0.36 to 0.55 , similar to what was observed by Sidrim and colleagues 2010, who also isolated a high percentage of strongly positive phospholipase producing $C$. albicans. These findings corroborate those of Cafarchia and colleagues (2006b), who stated that raptors are carriers of potentially pathogenic and zoonotic yeast species, once elevated phospholipase production may be associated with enhanced virulence (Ibrahim et al., 1995; Ghannoum, 2000).

Another noteworthy finding of this study was the recovery of three resistant Candida isolates from the crop of two R. magnirostris ( 1 C. albicans and 1 C. tropicalis) and the cloaca of one $C$. atratus ( 1 C. albicans). These three birds were free-ranging individuals from the city of Fortaleza that had recently been taken into captivity to recover from small traumas. Thus, it is known that they had never been subjected to antifungal therapy. These species are very common in urban centres, contributing to their exposure to various chemical compounds, including those from improper waste management. From 1978 to 1998, the municipal solid waste of the city of Fortaleza was destined to an open-air garbage dump, located near the Cocó River Basin. Currently, although officially deactivated, the site still receives solid waste and still contributes to environmental pollution, especially because the residues and the area do not receive proper treatment (Santos and Rigotto, 2008).

In addition, the occurrence of cross-resistance to medical and agricultural azoles in Candida spp. (Müller et al., 2007) may also have contributed to these findings, once the two $R$. magnirostris individuals may have been exposed to azoles used in agriculture through the ingestion of small herbivore preys. However, this possibility seems less likely because Fortaleza is a big city where agriculture is not a common practice. Besides, the American black vulture (C.atratus) is a scavenger species (Carvalho et al., 2003), thus, prey ingestion would not play an important role for the recovery of resistant yeasts.

Azole resistance has also been observed in environmental isolates of Aspergillus spp. (Mortensen et al., 2010) and these resistant strains are also capable of infecting humans, resulting in azole-resistant cases of aspergillosis (Snelders et al., 2009). Similarly, these findings concerning azole resistance in Candida strains from raptors also raise an important public health issue, considering that animals can represent a source of Candida spp. infections for humans (Edelmann et al., 2005).

Historically, raptors have been used as sentinels for the presence of environmental contaminants, such as pesti- 
cides and heavy metals (Marrow et al., 2009). Because of their predatory behaviour, once microorganisms from the gut of preys colonize the gastrointestinal tract of raptors, the use of these birds as indicators of the presence of resistant bacteria has also been encouraged, since their microbiota reflects the environment they inhabit (Marrow et al., 2009; Guenther et al., 2010).

Considering the high rate of yeast isolation from animal sources, especially Candida spp. (Melville et al., 2004; Vieira and Acqua-Coutinho, 2009; Brilhante et al., 2010; 2011), these microorganisms could also provide valuable information on animals' habitats. Based on this, Candida spp. could be used as indicators of environmental pollution, through phenotypical assessment of their in vitro susceptibility profile, since azole resistance is frequently associated with the overexpression of efflux pumps (Feng et al., 2010), which is possibly related to the exposure of these microorganisms to chemical compounds (e.g. pollutants), as an unspecific mechanism of cellular detoxification (Jungwirth and Kuchler, 2006). Additionally, the use of raptors for this purpose seems particularly interesting because free-ranging individuals are commonly taken to rehabilitation centres where they can easily and noninvasively be assessed, contributing to environmental monitoring.

\section{Acknowledgements}

This study was supported by CNPq, Brazil (302574/2009-3, PROTAX 562296/2010-7 and PRONEX 2155-6) and CAPES, Brazil (PNPD 2103/2009).

\section{References}

Brilhante, R.S., Castelo-Branco, D.S.C.M., Soares, G.D., Astete-Medrano, D.J., Monteiro, A.J., Cordeiro, R.A., et al. (2010) Characterization of the gastrointestinal yeast microbiota of cockatiels (Nymphicus hollandicus): a potential hazard to human health. J Med Microbiol 59: 718723.

Brilhante, R.S.N., Paiva, M.A.N., Sampaio, C.M.S., Teixeira, C.E.C., Castelo-Branco, D.S.C.M., Leite, J.J.G., et al. (2011) Yeasts from Macrobrachium amazonicum: a focus on antifungal susceptibility and virulence factors of Candida spp. FEMS Microbiol Ecol 76: 268-277.

Cafarchia, C., Camarda, A., Romito, D., Campolo, M., Quaglia, N.C., Tullio, D., and Otranto, D. (2006a) Occurrence of yeasts in cloacae of migratory birds. Mycopathologia 161: 229-234.

Cafarchia, C., Romito, D., latta, R., Camarda, A., Montagna, M.T., and Otranto, D. (2006b) Role of birds of prey as carriers and spreaders of Cryptococcus neoformans and other zoonotic yeasts. Med Mycol 44: 485-492.

Carvalho, L.R., Farias, L.M., Nicoli, J.R., Silva, M.C.F., Corsino, A.T.S.M., Lima, L.A., et al. (2003) Dominant culturable bacterial microbiota in the digestive tract of the American black vulture (Coragyps atratus Bechstein 1793) and search for antagonistic substances. Braz $J$ Microbiol 34: 218-224.

Clinical and Laboratory Standards Institute (CLSI) (2008) Reference method for broth dilution antifungal susceptibility testing of yeasts. Aproved standart M27-A3, Wayne, USA.

Edelmann, A., Krüger, M., and Schmid, J. (2005) Genetic relationship between human and animal isolates of Candida albicans. J Clin Microbiol 43: 6164-6166.

Feng, L., Wan, Z., Wang, X., Li, R., and Liu, W. (2010) Relationship between antifungal resistance of fluconazole resistant Candida albicans and mutations in ERG11 gene. Chin Med J 123: 544-548.

Ghannoum, M.A. (2000) Potential role of phospholipases in virulence and fungal pathogenesis. Clin Microbiol Rev 13: 122-143.

Guenther, S., Grobbel, M., Lübke-Becker, A., Friedrich, A.G.N.D., Wieler, L.H., and Ewers, C. (2010) Antimicrobial resistance profiles of Escherichia coli from common European wild bird species. Vet Microbiol 144: 219-225.

Ibrahim, A.S., Mirbod, F., Filler, S.G., Banno, Y., Cole, G.T., Kitajima, Y., et al. (1995) Evidence implicating phospholipase as a virulence factor of Candida albicans. Infect Immun 63: 1993-1998.

Instituto Chico Mendes de Conservação da Biodiversidade (ICMBio) (2008) Plano De Ação Nacional Para A Conservação De Aves De Rapinas. Brasília, Brazil: ICMBio.

Integrated Taxonomic Information System (ITIS) [WWW document]. URL http://www.itis.gov (Accessed on 21 June 2011).

Jungwirth, H., and Kuchler, K. (2006) Yeast ABC transporters - a tale of sex, stress, drugs and aging. FEBS Lett 580: 1131-1138.

Kolaczkowski, M., Michalak, K., and Motohashi, N. (2003) Phenothiazines as potent modulators of yeast multidrug resistance. Int J Antimicrob Ag 22: 279-283.

Marrow, J., Whittington, J.K., Mitchell, M., Hoyer, L.L., and Maddox, C. (2009) Prevalence and antibiotic-resistance characteristics of Enterococcus spp. isolated from freeliving and captive raptors in central Illinois. $J$ Wildlife Dis 45: 302-313.

Melville, P.A., Cogliati, B., Mangiaterra, M.B.B.C.D., Peres, M.R., Moura, S.C.A., Matsuda, L., et al. (2004) Determinação da microbiota presente na cloaca e orofaringe de avestruzes (Struthio camelus) clinicamente sadios. Cienc Rural 34: 1871-1876.

Mortensen, K.L., Mellado, E., Lass-Flörl, C., RodriguezTudela, J.L., Johansen, H.K., and Arendrup, M.C. (2010) Environmental study of azole-resistant Aspergillus fumigatus and other Aspergilli in Austria, Denmark, and Spain. Antimicrob Agents Chemother 54: 4545-4549.

Müller, F.M.C., Staudigel, A., Salvenmoser, S., Tredup, A., Miltenberger, R., and Herrmann, J.V. (2007) Crossresistance to medical and agricultural azole drugs in yeasts from the oropharynx of human Immunodeficiency virus patients and from environmental Bavarian vine grapes. Antimicrob Agents and Chemother 51: 3014-3016.

Pfaller, M.A., Andes, D., Diekema, D.J., Espinel-Ingroff, A., and Sheehan, D. (2010) Wild-type MIC distributions, epidemiological cutoff values and species-specific clinical breakpoints for fluconazole and Candida: time for 
193 R. S. N. Brilhante et al.

harmonization of CLSI and EUCAST broth microdilution methods. Drug Resist Update 13: 180-195.

Price, M.F., Wilkinson, I.D., and Gentry, L.O. (1982) Plate method for detection of phospholipase activity of Candida albicans. Sabouraudia 22: 201-207.

Santos, G.O., and Rigotto, R.M. (2008) Possíveis impactos sobre o ambiente e a saúde humana decorrentes dos lixões inativos de Fortaleza (CE). Health Environ $J$ 9: $55-62$.

Sidrim, J.J.C., Castelo-Branco, D.S.C.M., Brilhante, R.S.N., Soares, G.D.P., Cordeiro, R.A., Monteiro, A.J., and Rocha, M.F.G. (2010) Candida species isolated from the gastrointestinal tract of cockatiels (Nymphicus hollandicus): in vitro antifungal susceptibility profile and phospholipase activity. Vet Microbiol 145: 324-328.

Snelders, E., Huis in 't Veld, R.A.G., Rijs, A.J.M.M., Kema, G.H.J., Melchers, W.J.G., and Verweij, P.E. (2009) Possible environmental origin of resistance of Aspergillus fumigates to medical triazoles. Appl Environ Microbiol 75: 4053-4057.

Vieira, R.G., and Acqua-Coutinho, S.D. (2009) Phenotypical characterization of Candida spp. isolated from crop of parrots (Amazona spp.). Pesqui Vet Bras 29: 452456. 